\title{
Comparing the egg ultrastructure of three Psorophora ferox (Diptera: Culicidae) populations
}

\author{
C. F. Mello ${ }^{a, b}, J$. R. Santos-Mallet ${ }^{c}$, A. Tátila-Ferreira ${ }^{a, b}$ and J. Alencar ${ }^{a} *$ \\ aDiptera Laboratory, Oswaldo Cruz Institute - FIOCRUZ, Avenida Brasil, n. 4365, Manguinhos, \\ CEP 21040-900, Rio de Janeiro, RJ, Brazil \\ 'Postgraduate Program on Animal Biology, Institute of Biology, Federal Rural University of Rio de Janeiro - UFRRJ, \\ Rd BR 465, Km 7, CEP 23897-000, Seropédica, RJ, Brazil \\ 'Interdisciplinary Entomological Surveillance Laboratory in Diptera and Hemiptera, Oswaldo Cruz Institute - FIOCRUZ, \\ Avenida Brasil, n. 4365, Manguinhos, CEP 21040-900, Rio de Janeiro, RJ, Brazil \\ *e-mail: jalencar@ioc.fiocruz.br
}

Received: November 10, 2016 - Accepted: March 28, 2017 - Distributed: October 31, 2018

(With 1 figure)

\begin{abstract}
Characterising the external morphology of mosquito eggs is important, since it facilitates the identification of material from breeding sites and contributes to the understanding of species biology and group systematics. Therefore, was to compare eggs from different Psorophora ferox populations using scanning electron microscopy (SEM). Eggs were obtained from adult female of Ps. ferox collected in the Poços das Antas Biological Reserve (Reserva Biológica de Poços das Antas, Rio de Janeiro, Brazil). From each female, one portion of eggs $(n=5)$ was reared for identification purposes, and the second portion $(\mathrm{n}=10)$ was examined using SEM for morphometric analysis. The egg morphology was then compared to that of eggs from Ps. ferox populations in Florida (USA) and Arena (Trinidad). The exochorion ornamentation of the populations differs considerably in the morphology of the tubercles of the chorionic cells, external chorionic reticulum, micropylar collar, and micropyle.
\end{abstract}

Keywords: scanning electron microscopy, mosquitoes, Aedini, morphometry, egg.

\section{Comparação da ultraestrutura de ovos de três populações de Psorophora ferox (Diptera: Culicidae)}

\section{Resumo}

Caracterização da morfologia externa dos ovos do mosquito é importante, uma vez que facilita a identificação de materiais a partir de locais de reprodução e contribui para a compreensão da biologia das espécies e sistemática do grupo. O objetivo do presente estudo foi comparar os ovos de diferentes populações Psorophora ferox usando MEV. Os ovos foram obtidos a partir de fêmeas de Ps. ferox que foram coletadas na Reserva Biológica de Poço das Antas (Reserva Biológica de Poço das Antas, Rio de Janeiro, Brasil). A partir de cada fêmea, uma parte dos ovos $(\mathrm{n}=5)$ foi criado para fins de identificação, e uma segunda parte $(\mathrm{n}=10)$ foi examinado usando MEV para análise morfométrica. Foi então comparada a morfologia dos ovos de populações de PS.ferox da Flórida (EUA) e Arena (Trinidad). A ornamentação do exocório das populações difere consideravelmente na morfologia dos tubérculos das células coriônicas, retículo coriônico externo, colar micropilar e micrópila.

Palavras-chave: microscopia eletrônica de varredura, mosquitos, Aedini, morfometria, ovo.

\section{Introduction}

The tribe Aedini (Culicidae) includes 1,255 species, of which several are medically important vectors of yellow fever, dengue, and other arboviruses. Several morphological aspects of these species have been investigated; however, the eggs of only $16 \%$ of the species in tribe Aedini have been studied, mostly by light microscopy (Reinert, 2005). Approximately $30 \%$ of the species of Psorophora have their eggs described and illustrated (Reinert, 2010;
Pacheco et al., 2012). The characterisation of insect eggs using SEM facilitates the direct identification of insect species and eliminates the need to foster the development of eggs into identifiable phases via laboratory rearing, which is usually laborious, costly, and carries certain risks if the insect is a disease vector. In addition, the information obtained using SEM can also be used for phylogenetic studies. 
Psorophora spp., which are commonly known as flood mosquitos, lay their eggs in ground water, much like other Aedini mosquitoes, and frequently wait for flooding before laying eggs. Most species of the genus are widely distributed, and Psorophora (Janthinosoma) ferox (Humboldt 1819) has been reported to occur in the three Americas from Ontario (south Canada) to northern Argentina and Uruguay, with a distribution that spreads east of the Andes Cordillera and includes the central, eastern, and southeastern areas of the USA, Mexico, Central America, the Antilles, Colombia, Venezuela and Brazil (Forattini, 2002; Orlandin et al., 2017). Ps. ferox has been reported to harbour several arboviruses, namely Rocio (Lopes et al., 1981), West Nile virus (Kulasekera et al., 2001), eastern equine encephalitis (Cupp et al., 2004), and Ilheus virus (Turell et al., 2005), and were also shown to transmit Rocio experimentally (Mitchell et al., 1986).

Although Ligth microscope (LM) has been used since the beginning of the $20^{\text {th }}$ century and continues to be used sporadically, Scanning electron microscopy (SEM) has facilitated more detailed descriptions of egg surfaces since the 1960s. Linley and Chadee (1990) used SEM to determine the exochorion patterns of eggs from several Psorophora ferox populations. They reported that the exochorion patterns of Ps. ferox from Florida (USA) were clearly different from those of Ps. ferox from Trinidad, in both the number and shape of the external chorionic tubers in each chorionic cell.

The present study aimed to compare Ps. ferox eggs from different geographical regions, using SEM to perform a morphometric analysis of the main exochorion structures.

\section{Material and Methods}

To obtain eggs, female Ps. ferox were collected from Poço das Antas Biological Reserve (Reserva Biológica Poço das Antas; REBIO-PA), which and includes 5,226 ha (perimeter of $44 \mathrm{~km}$ ) and is located in the central part of the Silva Jardim municipality, Rio de Janeiro, Brazil (22 33'11.4" S and 42 17 '49.8' W.). Five blood-fed females were captured, sampling was conducted over 2 months (march and april 2015), using an oral suction tube, and taken to the laboratory, where they were maintained in $30 \mathrm{ml}$ plastic vials until they laid eggs (4-5 d).

Immediately after oviposition, 15 eggs were taken from each female: five eggs were reared in a total of 25 , and ten were submitted to morphometric analyses in a total of 50. The species was identified using Forratini dichotomous keys (2002).

For the SEM analysis, the eggs were removed from the filter paper using a brush, fixed in $2.5 \%$ glutaraldehyde, and post-fixed in $1 \%$ osmium tetroxide, both in $0.1 \mathrm{M}$ sodium cacodylate buffer at $7.2 \mathrm{pH}$. After being washed in the buffer, the eggs were dehydrated in an increasing ethanol series, and critical-point dried using super-dry $\mathrm{CO}^{2}$ in a Balzers device (Hayat, 1970). The eggs were then mounted on metal supports, coated with gold, and observed using a JEOL JSM 6390LV scanning electron microscope (JEOL, Ltd., Akishima, Tokyo, Japan) at 200-5,000× magnification. The eggs were also photomicrographed in both dorsal and ventral positions in order to observe both the exochorion and micropyle.

Morphological measurements were directly performed by measuring the features on the photomicrographs, using Semafore digital slow scan image recording system, version 3.1 (Insinooritoimisto J. Rimppi Oy, Ojakkala, Finland), and analysed using SEM Control User Interface version 8.24 (JEOL, Ltd.), which was coupled to the microscope. The measured parameters included total length, total width, chorionic tubercle diameter, micropyle, and micropyle annexes, for comparision with the data obtained by Linley and Chadee (1990). The terminology used to describe the eggs followed Harbach and Knight (1980), and the genera have been abbreviated as proposed by Reinert (2009).

\section{Results}

The Ps. ferox eggs are deep black in colour and separately, strongly adherent to the surface. When observed by SEM, the eggs were elliptical, with a mean length and width of 816.8 and $205.6 \mu \mathrm{m}$, respectively, and egg index (length/width ratio) was 3.97. (Figure 1A). The exochorion presented a regular distribution of chorionic reticulum, with hexagonal and sometimes pentagonal chorionic cells internally coated by small tubercles (length: 12.9-17.9 $\mu \mathrm{m}$; width: 5.14-6.22 $\mu \mathrm{m}$ ). The small tubercles were irregularly shaped, being rectangular, rounded, square, or tubular, and their densities ranged from 18 to 22 tubercles per cell $(16.2 \pm 3.21 ; n=10)$. In addition, the exochorion also presented large, conical tubercles (length 13-18 $\mu \mathrm{m}$; width 5.1-6.2 $\mu \mathrm{m}$ ) at one extremity of the chorionic cells (Figure 1B), which contrasted with the patterns observed in the eggs of other Psorophora spp. (Table 1), thus distinguishing the eggs of Ps. ferox from those of its congeners. Meanwhile, the tubercles exhibited a porous appearance, without any nodules on their surface, and the surface of the chorionic reticulum in the anterior region of the egg was not rough. The micropylar collar was prominent and continuous and presented a conspicuous micropylar disc (diameter: $20.4 \mu \mathrm{m}$, thickness: $7.96 \mu \mathrm{m}$; Figure 1C) at its centre; and the micropyle (diameter: $2.4 \mu \mathrm{m}$ ) was observed in the centre of this disc (Figure 1D). The characteristics of the tubercles of specimens of Psorophora (Janthinosoma) ferox of three different regions are shown in the table 2 .

\section{Discussion}

The measurements of the Ps. ferox eggs obtained here differed from those eggs from populations in Florida and Trinidad, which were described by Linley and Chadee (1990).

In general, the eggs from REBIO-PA were smaller, although some were within the size range observed in eggs from Florida. The size and number of tubercles also differed among the three locations (Table 1), which 
suggested intraspecific differences. The mean length and width of Ps. ferox eggs from Illinois (Horsfall et al., 1952) were lower than those of eggs from Florida, Trinidad, and REBIO-PA, but it was not possible to compare

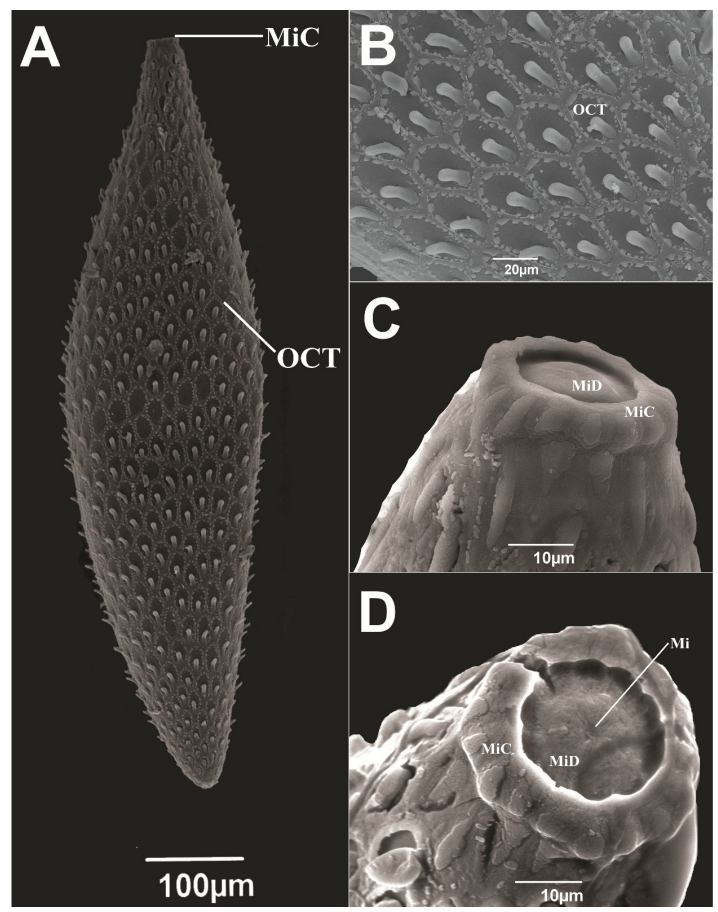

Figure 1. Egg of Psorophora (Janthinosoma) ferox. (A) ventral (upper) view; (B) typical ornamentation of the outer chorionic reticulum showing two types of tubercles; (C) anterior region of the egg showing micropylar apparatus, formed by a micropilar disc with a well evidenced frame; (D) anterior pole of egg, with micropyle. Mi, micropyle; MiC, micropylar collar; MiD, micropylar disc; OCT, outer chorionic tubercle. any of the other features of eggs from Illinois, since the study was based on light microscope observations. In comparison to Psorophora varipes (Coquillett 1904) (Horsfall et al., 1952) and Ps. albigenu (Lutz 1908) (Pacheco et al., 2012), the PS. ferox eggs also presented a longer cylinder-shaped tubercle at one extremity and were distinctly longer, thus characterising the eggs of Ps. ferox from those of other species.

Exochorion structures exhibit remarkable variation, and characterising these structures using SEM greatly enhances morphological studies that were previously limited to LM and facilitates the identification of Culicidae taxa from different species complexes (Forattini, 2002). Although Horsfall et al. (1952) devised a taxonomic key for several North American Psorophora species, the key was based on LM and could potentially be refined using information obtained by SEM. However, of the 17 Psorophora species (of 52 species) for which egg morphology has been reported, most descriptions are based on LM (Reinert, 2005), and of the 21 Psorophora species in Brazil, egg descriptions have only been provided for nine species, with only three species described using SEM: Ps. cingulata (Fabricius 1805), Ps. albigenu, and Ps. ferox. This scarcity of information, along with the wide distribution of most species, emphasises the need for investigating the egg morphology of other species.

In the present study, the SEM-based description of Ps. ferox eggs from REBIO-PA and comparison to other Ps. ferox populations revealed few dissimilarities in the exochorion morphology. However, it was verified difference in the measurements of the eggs of Trinidad and Florida, when compared to Brazil in relation to the lenght, width and characteristics of the tubercles being the samples of Brazil the most disparate, thus contributing to inter- and intraspecific taxonomy of Culicidae species.

Table 1. Dimensions of eggs of specimens of Psorophora (Janthinosoma) ferox of three different regions.

\begin{tabular}{|c|c|c|c|c|c|c|}
\hline \multirow{2}{*}{ Specimen } & \multicolumn{2}{|c|}{ Lenght $\mu \mathrm{m}$} & \multicolumn{2}{|c|}{ Widht $\mu \mathrm{m}$} & \multicolumn{2}{|c|}{ Lenght/Widht ratio } \\
\hline & Mean \pm SE & Range & Mean \pm SE & Range & Mean \pm SE & Range \\
\hline Ps ferox $(* \mathrm{Fl})$ & $904.5 \pm 13.7$ & $845.5-963.6$ & $250.2 \pm 3.6$ & $227.9-265.5$ & $3.62 \pm 0.03$ & $3.44-3.75$ \\
\hline Ps ferox (*Tr.) & $918.3 \pm 1.9$ & $911.0-927.7$ & $316.7 \pm 1.7$ & $311.1-322.2$ & $2.90 \pm 0.02$ & $2.83-3.04$ \\
\hline Ps ferox $(\mathrm{Br})$ & $816.8 \pm 19.4$ & $760.3-844.7$ & $205.6 \pm 5.5$ & $190.3-216.7$ & $3.97 \pm 0.04$ & $3.88-4.08$ \\
\hline
\end{tabular}

(Fl.): Vero Beach-Florida (EUA); (Tr.): Arena (Trinidad); (Br.) Poço das Antas Biological Reserve-Rio de Janeiro, Brazil. *From Linley and Chadee (1990).

Table 2. Characteristics of the tubercles of specimens of Psorophora (Janthinosoma) ferox of three different regions.

\begin{tabular}{lccccccc}
\hline \multirow{2}{*}{ Specimen } & \multicolumn{3}{c}{ Small tubercles } & & \multicolumn{3}{c}{ Higher tubercles } \\
\cline { 2 - 3 } \cline { 7 - 8 } & Amount & Mean \pm SE & Range & & Amount & Length & Width \\
\hline Ps ferox $\left({ }^{*} \mathrm{~F} 1\right)$ & 36 & $32.9 \pm 1.7$ & $17-51$ & & 36 & $13-25$ & $5.5-7$ \\
Ps ferox $(* \mathrm{Tr})$ ) & 28 & $27.5 \pm 0.6$ & $23-35$ & & 28 & $13-25$ & $5.5-7$ \\
Ps ferox $(\mathrm{Br})$ & 26 & $16.3 \pm 0.6$ & $10-22$ & & 26 & $13-18$ & $5.1-6.2$ \\
\hline
\end{tabular}

(Fl.): Vero Beach-Florida (EUA); (Tr.): Arena (Trinidad); (Br.) Poço das Antas Biological Reserve-Rio de Janeiro, Brazil. *From Linley and Chadee (1990). 


\section{Acknowledgements}

We thank the Foundation for Supporting Research from the State of Rio de Janeiro - FAPERJ (contract 112.076/2012) and the National Council for Scientific and Technological Development - CNPq (301345/2013-9) for their financial support.

\section{References}

CUPP, E.W., ZHANG, D., YUE, X., CUPP, M.S., GUYER, C., SPRENGER, T.R. and UNNASCH, T.R., 2004. Identification of reptilian and amphibian blood meals from mosquitoes in an eastern equine encephalomyelitis virus focus in central Alabama. The American Journal of Tropical Medicine and Hygiene, vol. 71, no. 3, pp. 272-276. PMid:15381805.

FORATTINI, O., 2002. Culicidologia médica. vol. 2. São Paulo: Editora da Universidade de São Paulo. 860 p.

HARBACH, R.E., and KNIGHT, K.L., 1980. Taxonomists' glossary of mosquito anatomy. Marlton: Plexus Publishing. $415 \mathrm{p}$.

HAYAT, M.A., 1970. Principles and techniques of electron microscopy: biological applications. vol. I. New York: Van Nostrand Reinhold. 412 p.

HORSFALL, W.R., MILES, R.C. and SOKATCH, J.T., 1952. Eggs of floodwater mosquitoes. I: species of Psorophora (Diptera: Culicidae). Annals of the Entomological Society of America, vol. 44, no. 4, pp. 618-624. http://dx.doi.org/10.1093/aesa/45.4.618.

KULASEKERA, V.L., KRAMER, L., NASCI, R.S., MOSTASHARI, F., CHERRY, B., TROCK, S.C. and MILLER, J.R., 2001. West Nile virus infection in mosquitoes, birds, horses, and humans, Staten Island, New York, 2000. Emerging Infectious Diseases, vol. 7, no. 4, pp. 722-725. PMid:11589172. http://dx.doi.org/10.3201/ eid0704.017421.

LINLEY, J.R., and CHADEE, D.D., 1990. Fine structure of the eggs of Psorophora columbiae, Ps. cingulata and Ps. ferox (Diptera: Culicidae). Proceedings of the Entomological Society of Washington, vol. 92, no. 3, pp. 497-511.

LOPES, O.S., SACCHETTA, L.A., FRANCY, D.B., JAKOB, W.L. and CALISHER, C.H., 1981. Emergence of a new arbovirus disease in Brazil III. Isolation of Rocio virus from Psorophora ferox (Humboldt, 1819). American Journal of Epidemiology, vol. 113, no. 2, pp. 122-125. PMid:6110335.

MITCHELL, C.J., FORATTINI, O.P. and MILLER, B.R., 1986. Vector competence experiments with Rocio virus and three mosquito species from the epidemic zone in Brazil. Revista de Saude Publica, vol. 20, no. 3, pp. 171-177. PMid:2880387. http:// dx.doi.org/10.1590/S0034-89101986000300001.

ORLANDIN, E., SANTOS, E.B., PIOVESAN, M., FAVRETTO, M.A., SCHNEEBERGER, A.H., SOUZA, V.O., MULLER, G.A. and WAGNER, G., 2017. Mosquitoes (Diptera: Culicidae) from crepuscular period in an Atlantic Forest area in Southern Brazil. Brazilian Journal of Biology $=$ Revista Brasleira de Biologia, vol. 77, no. 1, pp. 60-67. PMid:27383000. http://dx.doi. org/10.1590/1519-6984.09815.

PACHECO, J.B., SANTOS-MALLET, J.R., GUIMARÃES, A.É., COSTA, J.M. and ALENCAR, J., 2012. Ultrastructure and morphometry of the egg of Psorophora albigenu Lutz, 1908 (Diptera: Culicidae). Micron, vol. 43, no. 2-3, pp. 418-421. PMid:22154069. http://dx.doi.org/10.1016/j.micron.2011.10.014.

REINERT, J.F., 2005. List of species described in the egg stage of tribe Aedini (Diptera: Culicidae) with their literature citations. Journal of the American Mosquito Control Association, vol. 21, pp. 252-262. PMid:16252514. http://dx.doi.org/10.2987/8756971X(2005)21[252:LOSDIT]2.0.CO;2.

REINERT, J.F., 2009. List of abbreviations for currently valid generic-level taxa in family Culicidae (Diptera). European Mosquito Bulletin, vol. 27, pp. 68-76.

REINERT, J.F., 2010. Species of mosquitoes (Diptera: Culicidae) with published illustrations and/or descriptions of eggs summary. European Mosquito Bulletin, vol. 28, pp. 182-186.

TURELL, M.J., O'GUINN, M.L., JONES, J.W., SARDELIS, M.R., DOHM, D.J., WATTS, D.M., FERNANDEZ, R., TRAVASSOS DA ROSA, A., GUZMAN, H., TESH, R., ROSSI, C.A., LUDWIG, V., MANGIAFICO, J.A., KONDIG, J., WASIELOSKI JUNIOR, L.P., PECOR, J., ZYZAK, M., SCHOELER, G., MORES, C.N., CALAMPA, C., LEE, J.S. and KLEIN, T.A., 2005. Isolation of viruses from mosquitoes (Diptera: Culicidae) collected in the Amazon Basin region of Peru. Journal of Medical Entomology, vol. 42, no. 5, pp. 891-898. PMid:16366001. http://dx.doi.org/10.1093/jmedent/42.5.891. 